Int. J. Dev. Biol. 49: 633-643 (2005)

doi: $10.1387 / \mathrm{ijdb} .052020 \mathrm{pr}$

\title{
Flower and fruit development in Arabidopsis thaliana
}

\author{
PEDRO ROBLES ${ }^{1}$ and SORAYA PELAZ*,2 \\ ${ }^{1}$ División de Genética and Instituto de Bioingeniería, Universidad Miguel Hernández, Campus de Elche, Elche, Alicante, Spain and \\ ${ }^{2}$ ICREA and LGMV (Institució Catalana de Recerca i Estudis Avançats and Laboratori de Genètica Molecular Vegetal, CSIC-IRTA), \\ Barcelona, Spain
}

\begin{abstract}
The study of flower development has experienced great advances over the last 15 years. The most important landmark was the proposal of the ABC model in which three different functions of overlapping activities account for the development of the four rings of organs of the eudicot flower. Most interestingly, during recent years this simple and elegant model has been broadly accepted and is applicable to a wide range of plant species. However, recent advances in the characterization of protein interactions and the discovery of the SEPALLATA genes that are required for proper floral organ development have led to a revision of the $A B C$ model. The largely accepted floral quartet model, which includes the new SEPALLATA function, postulates that the development of a specific floral organ is achieved by the formation of a single complex of different MADS-box proteins. The ultimate fate of the flower is to become a fruit, ensuring dispersal of the seeds and therefore survival of the species. The Arabidopsis fruit is a silique or pod. Only in the last five years important advances have been made in establishing the differentiation of the tissues required for the opening of the fruit: the valve margins and dehiscence zone. Classical genetic analyses and molecular biology approaches have pointed to the involvement of the transcription factors SHP, ALC and IND in the formation of these tissues and of FUL and RPL in repressing this identity in the bordering tissues, valves and replum, respectively.
\end{abstract}

KEY WORDS: Arabidopsis, flower development, fruit patterning

\section{An introduction to flower development}

Angiosperms, the flowering plants, develop complex reproductive structures, the flowers. In spite of the great diversity in the form, color and structure of the flowers, they share a common characteristic, the basic construction plan. Most flowers consist of rings of floral organs, with external sterile organs surrounding the reproductive structures located in the center. A typical eudicot flower is composed of four rings, or whorls, of organs. The outermost whorl is composed of sepals and within this whorl are the petals, then the stamens (the male reproductive organs) and finally the carpels or female structures in the center of the flower (Figure 1). Later on in development, the fertilized carpels will give rise to the fruit.

The last 15 years have been very fruitful for the study of the flower development and we now understand better how a flower develops. Most of the genetic and molecular studies that have played a key role in this understanding of flower development have been performed in three distant eudicot plants, Arabidopsis thaliana, Antirrhinum majus and Petunia hybrida. These studies, in conjunction with the initial cloning of some of the genes involved in flower development, led to the proposal of the elegant and broadly accepted ABC model of flower development (Bowman etal., 1991, Coen and Meyerowitz, 1991). Because this model proved valid for several other plant species (Rutledge et al., 1998, Tandre et al., 1998, Ambrose et al., 2000, Fornara et al., 2003) we can consider this $A B C$ model as universal. However, it is during the last five years that new data have led to the proposal of a revised version of the classic ABC model, broadly accepted as the floral quartet model. The revised model includes a new function that is required for the development of the four types of floral organs and proposes that the development of each organ is achieved by the formation of large protein complexes.

\section{The ABC model}

Genetic studies in Arabidopsis thaliana and Antirrhinum majus led to the proposal of the landmark $A B C$ model of flower development (Bowman et al., 1991, Coen and Meyerowitz, 1991). This model proposes that three different activities, A, B and C, alone or in combination specify the distinct organs of the four whorls of the flower. A function alone is responsible of the sepal development in the outermost whorl, A and B functions together specify the petals 

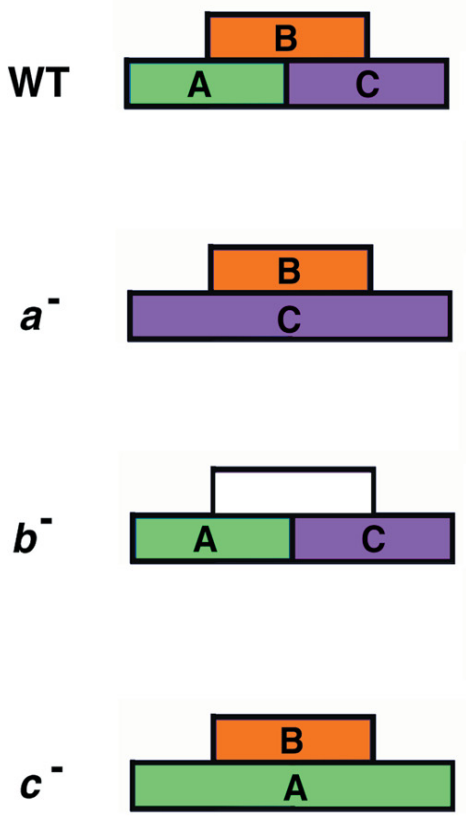
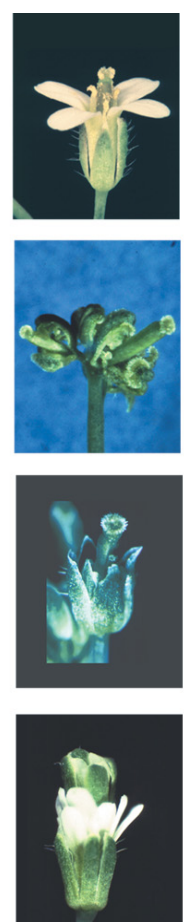

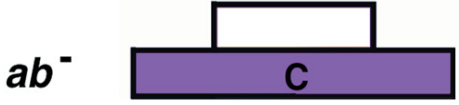

ac

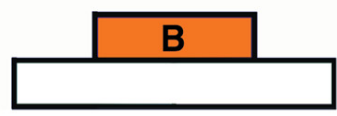

bc

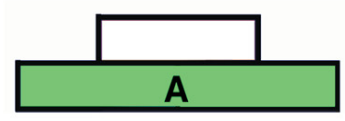

$a b c^{-}$
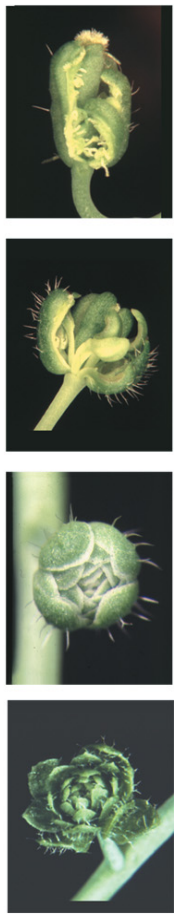

Fig. 1. ABC model and floral organ identity mutants of Arabidopsis. Pictures of wild type and single, double and triple mutant flowers are shown next to the diagram of the $A B C$ activities for each phenotype.

in the second whorl, B and C determine the stamens in the third whorl and $C$ function specifies the carpels in the center of the flower. The model also proposes that $A$ and $C$ functions are mutually antagonistic (Figure 1). According to the model, mutant flowers in the A function genes have the sepals transformed into carpels and the petals into stamens due to the ectopic $\mathrm{C}$ activity in the outer whorls of the flower. The resultant flower is composed of carpels-stamens-stamens-carpels, from the outer to the inner whorl. Likewise, the $c$ mutant flowers, with ectopic A function, have their stamens transformed into petals and the carpels are replaced by another flower which repeats the same pattern, resulting in an indeterminate flower composed of sepals and petals. In $b$ mutants the flowers are composed of sepals-sepals-carpels-carpels. The $b c$ double mutants produce flowers composed of endless whorls of sepals. The $a b$ double mutants display flowers composed only of carpels and $a c$ mutant flowers show leaf-like organs in the first and fourth whorls and mosaic petal/stamen organs in the second and third whorls. Mutations in all three functions lead to the transformation of all floral organs into leaf-like organs, which supports the idea that the floral organs are modified leaves (Figure 1). These leaf-like organs would be the "ground state" and the acquisition of the $A, B$ and $C$ functions would evolve into floral organs.

\section{The genes}

The genes whose mutations give rise to the aberrant flowers described above were cloned. Of note is the fact that all these homeotic genes belong to the large MADS-box gene family of transcription factors, with the only exception being APETALA2 (AP2). When their expression patterns were analyzed (Figure 2B), their localization was found to be restricted to their domains of action except for AP2. AP2 RNA is expressed in all four whorls throughout flower development although $A P 2$ functions only in whorls 1 and 2 . Recently an exciting discovery explained this contradiction, $A P 2$ is translationally repressed by a microRNA which is active in whorls 3 and 4 (Chen, 2004). In Arabidopsis the A function genes are $A P E T A L A 1(A P 1)$ and $A P 2$, the $\mathrm{B}$ function genes are APETALA3 $(A P 3)$ and PISTILLATA $(P /)$ and the only C function gene is $A G A M O U S$ ( $A G)$. In Antirrhinum the ortholog of the A function $A P 1$ gene is SQUAMOSA (SQUA), B genes are $D E F I C I E N S$ (DEF) and GLOBOSA (GLO) and the two C function genes are PLENA (PLE) and FARINELL/ (FAR) (Riechmann and Meyerowitz, 1997b, reviewed in Davies et al., 1999). Orthologs of these Arabidopsis and Antirrhinum genes have been found in many other species, such as other eudicots (Angenent et al., 1994, Pnueli et al., 1994, Kramer et al., 1998, Vandenbussche et al., 2003), monocots (Mena etal., 1996, Kang et al., 1998, Ambrose et al., 2000) and even in gymnosperms (Tandre etal., 1995, Mouradov et al., 1998, Rutledge et al., 1998, Tandre et al., 1998, Mouradov et al., 1999, Zhang et al., 2004). Furthermore, the putative function of many of these genes has been confirmed by the characterization of mutants (Ambrose et al., 2000), by co-suppression or antisense phenotypes (Angenent et al., 1994, Pnueli et al., 1994, Kotilainen et al., 2000) or by constitutive expression studies (Kang et al., 1998, Rutledge et al., 1998).

\section{Transcriptional factors and protein interactions}

The name of the MADS-box family comes from the initials of the first four cloned genes of this kind, MCM1 (from yeast, Ammererer, 1990), AGAMOUS (Arabidopsis, Yanofsky etal., 1990), DEFICIENS (Antirrhinum, Sommer et al., 1990) and SRF (mammals, Norman et al., 1988). MADS-box proteins were first characterized in yeast 
and mammals, they are transcription factors that bind to DNA as dimers (Lamb and McKnight, 1991, Shore and Sharrocks, 1995). These proteins are composed of four different domains, the M, I, K and $\mathrm{C}$ domains (reviewed in Riechmann and Meyerowitz, 1997b, Figure $2 \mathrm{~A}$ ). The $\mathrm{M}$ or MADS domain is highly conserved and encodes the DNA binding region that has also been implicated in homodimer formation. The I region also participates in the homodimer interaction (Krizek and Meyerowitz, 1996b, Riechmann et al., 1996). The K domain, which is only present in plant proteins, was involved in protein-protein interactions (Krizek and Meyerowitz, 1996b, Mizukami et al., 1996, Riechmann et al., 1996, Fan et al., 1997, Moon et al., 1999, Pelaz et al., 2001a). The C terminus was proposed to be involved in transcriptional activation and in ternary complex formation (Huang etal., 1995, Egea-Cortines etal., 1999). Surprisingly, although the MADS domain is required for DNA binding and plays an important role in dimerization, the specificity of the MADS box gene function does not reside in the MADS domain. This was most convincingly shown by Krizek and Meyerowitz (1996b) and Riechmann and Meyerowitz (1997a), who demonstrated that the MADS box region can be replaced by the MADS box from a different gene without substantially altering its activity in planta. These studies demonstrated that much of the functional specificity of a given gene may involve protein interactions outside the MADS domain. These surprising results raised the question of how the floral organ identity genes manage to activate the specific target genes.

The ABC model proposes that these genes act in a combinatorial way to define organ identity. The genes involved in the A, B and $C$ activities have overlapping expression patterns and have been shown to dimerize using both a yeast model system and in vitro binding assays. Therefore the combinatorial activity could be the result of protein-protein interactions (reviewed in Davies et al., 1996, Fan et al., 1997, Riechmann and Meyerowitz, 1997b, EgeaCortines et al., 1999, Pelaz et al., 2001a). In order to study how the organ identity is defined through combinatorial protein interactions, it was necessary to uncover and characterize such interactions. The yeast two-hybrid system has been a successful method to detect dimers of the Antirrhinum MADS box proteins DEF, GLO and PLE (Davies et al., 1996), to find interactors of the Arabidopsis AG MADS box protein (Fan et al., 1997) and to discover those of AP1 and CAL (Pelaz et al., 2001a).

Based on the protein interactions uncovered using the yeast two-hybrid system, it became evident that the simplistic thinking of a cascade of transcription factors seemed insufficient to explain flower development. Since the end of 1999 the idea of how the floral organ identity genes accomplish their function has changed drastically. Previously, in vivo experiments to test the formation of ternary complexes among different $\mathrm{A}, \mathrm{B}$ and $\mathrm{C}$ proteins were lacking and some genes involved in flower development remained undiscovered. Powerful evidence in support of the formation of ternary complexes came from studies using a modified two-hybrid system (ternary factor trap) that allowed testing of the interaction of three different Antirrhinum MADS-box proteins, DEF, GLO and SQUA. When tested, this ternary complexDEF/GLO/SQUA showed an increased DNA binding affinity compared to either DEF/GLO heterodimer or SQUA homodimer (Egea-Cortines et al., 1999). Interestingly, apart from their independent floral meristem and organ identity functions (Huijser et al., 1992, Tröbner et al., 1992; reviewed in Riechmann and Meyerowitz, 1997b), DEF, GLO and
SQUA genes cooperate in the establishment of the whorled pattern of the flower, strongly suggesting the formation of a functional ternary complex in planta (Egea-Cortines et al., 1999).

\section{New members, new interactions}

Additional strong evidence was found in support of the ternary complex formation when the trio of redundant SEPALLATA (SEP) genes was discovered with reverse genetic techniques. Mutations in each of these Arabidopsis SEP genes led to subtle or no obvious altered phenotypes, however the triple mutant displayed a striking phenotype, a flower composed of endless whorls of sepals. Remarkably, it resembled the phenotype of the double $b c$ mutants, the petals and the stamens were transformed into sepals and the carpels were replaced by another flower which repeated the same pattern (Figure 1 and Figure $3 \mathrm{~A}$ ). This phenotype suggested that in the sep mutants, the $B$ and $C$ genes were not activated. On the contrary, although no $\mathrm{B}$ or $\mathrm{C}$ function was apparent in the sep triple mutant, the expression of the known $B$ and $C$ genes, $A P 3, P /$ and $A G$, was not altered (Pelaz et al., 2000). Therefore, the SEP genes do not transcriptionally activate the $B$ and $C$ genes since they are normally expressed in the sep triple mutant. However the $B$ and $C$ genes cannot function unless at least one of the redundant $S E P$ genes is also present. The $\mathrm{B}$ and $\mathrm{C}$ functions require the $S E P$ genes during flower development. The reverse is also true, in $b$ and $C$ mutants the SEP genes are also present (Mandel and Yanofsky, 1998 ) and they also require the functional activity of the other $B$ and $C$ genes. Therefore, the SEP genes define a new class of floral organ identity genes active in the three inner floral whorls and are

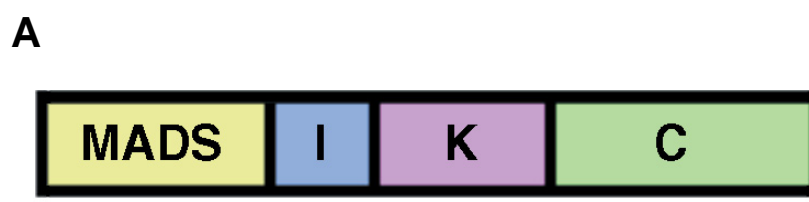

B
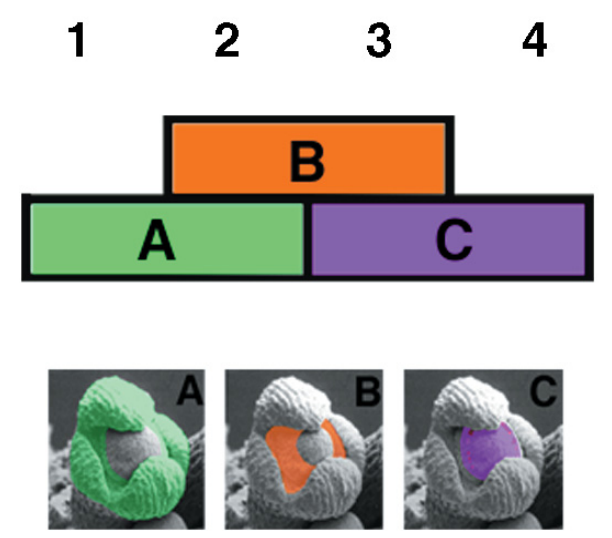

Fig. 2. Diagrams of protein structure and patterns of expression. Diagram of a MADS-box protein (A) and patterns of expression of the $A$ (green in the two outer whorls), B (orange, in petal and stamen primordia) and $C$ (purple in the two inner whorls) genes (B). 

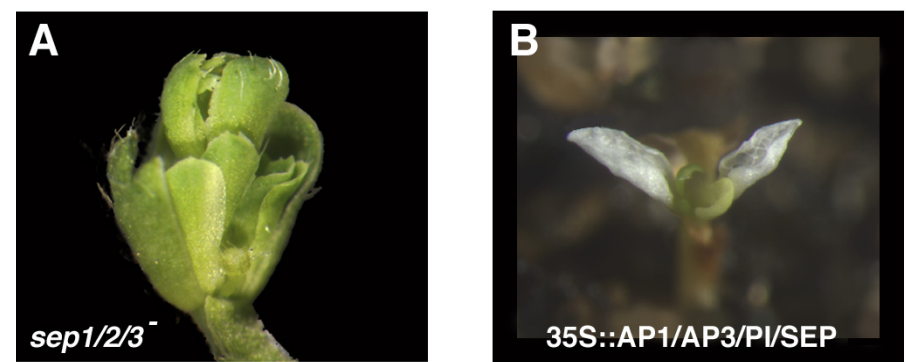

Fig. 3. sep triple mutant phenotype and 35S::AP1/AP3/PI/SEP phenotype. (A) The sepallata triple mutant displays flowers composed only of sepals. (B) The constitutive expression of AP1, AP3, PI and SEP genes results in the transformation of the vegetative leaves into petals.

required for the $B$ and $C$ functions. The SEP1/2/3 activity may result from protein-protein interactions with AP3, PI and AG (Pelaz et al., 2000) and are not required for the transcription of the $B$ and $C$ genes. Further support came from studies in petunia, tomato and Gerbera hybrida (Angenent et al., 1994, Pnueli et al., 1994, Kotilainen et al., 2000). Cosuppression of the petunia FBP2 gene and antisense lines of the tomato TM5 gene (both orthologs of SEP3) led to similar phenotypes to those obtained in the sep triple mutants (Angenent et al., 1994, Pnueli et al., 1994, Ferrario et al., 2003). In addition, antisense lines that downregulate GRCD1 expression in Gerbera hybrida (ortholog of SEP genes) produced a phenotype that resembled the one observed after the Gerbera $C$ function gene downregulation, although these $C$ genes were normally expressed. Therefore, the authors concluded that GRCD1 participates in the C function (Kotilainen et al., 2000).

In support of this idea, yeast two-hybrid assays showed that AP1 interacts with SEP3 and AG interacts with SEP1, SEP2 and SEP3 (Fan etal., 1997, Pelaz et al., 2001a). Moreover more recent studies using a modified version of the yeast 2-hybrid system have shown that the Arabidopsis AP3/PI heterodimer interacts with AP1 and with SEP3, making plausible the interaction of the four proteins at the same time (Honma and Goto, 2001). Honma and Goto also discovered that $A P 3 / P I$ interacts with $A G$ through SEP3 in the formation of the large protein complex AP3/PI/SEP3/AG. Similarly, ternary complexes of the Arabidopsis ortholog proteins have also been detected in Antirrhinum using ternary factor trap experiments (Egea-Cortines and Davies, 2000). The combination of the results obtained by genetic (Pelaz et al., 2000), 2 hybrid assay (Davies et al., 1996, Fan et al., 1997, Pelaz et al., 2001a) and the ternary factor trap experiments (Egea-Cortines et al., 1999, Honma and Goto, 2001, Ferrario et al., 2003, Immink et al., 2003), strongly support the possibility of the formation of large complexes of floral organ identity proteins in order to activate their specific target genes. Indeed, the $A G$ downstream gene SHP2 (Savidge et al., 1995) was not activated in sep triple mutants where $A G$ is normally expressed and so the presence of both SEP and AG functional proteins seemed to be required for SHP2 activation (Castillejo et al., in press).

\section{Transformation of leaves into floral organs}

According to the results described above, flower development would result from the formation of large transcription factor complexes that would be responsible for the activation of target genes.
This revolutionary concept contrasts with the original idea of flower development resulting from the independent action of transcription factors that specifically bind and activate the target genes. Besides this novel concept of how these MADS-box proteins work, new factors required for the $\mathrm{B}$ and $\mathrm{C}$ functions were discovered.

For a long time it was believed that the floral organs are modified leaves (Goethe, 1790). This belief was supported by the phenotype displayed by flowers missing the three $A B C$ activities whose organs are all leaf-like (Meyerowitz et al., 1989, Bowman et al., 1991, Figure 1). However, all attempts made to transform leaves into floral organs by ectopically expressing different floral organ identity genes largely failed. Only transformations within the floral context were achieved and very subtle modifications were found in cauline leaves (Mizukami and Ma, 1992, Krizek and Meyerowitz, 1996a). These experiments indicated that some floral factors were still missing. The SEP genes were good candidates for such missing factors since they are not normally expressed outside the flower and are required for the normal development of petals, stamens and carpels (Pelaz et al., 2000).

The combination of the required proteins described as involved in floral organ development, AP1, AP3, PI, AG and SEP, were chosen in the adequate combination in an attempt to transform leaves into floral organs. Notably, partial combinations such as AP1/AP3/PI or SEP/AP3/PI produced partial transformation of the cauline leaves into petals. In contrast, the vegetative rosette leaves were only slightly affected. Strikingly, the combination of all proteins involved in petal development, AP1, AP3, PI and SEP, produced the transformation of all leaves into petals (Honma and Goto, 2001, Pelaz et al., 2001b); Figure 3B). Scanning electronic microscope analysis established the complete transformation of the leaf cells into petal cells (Pelaz et al., 2001b). Furthermore, when $A G$ is expressed ectopically together with $A P 3, P /$ and $S E P 3$, the cauline leaves are converted into organs that resemble stamens (Honma and Goto, 2001). Therefore, these genes are necessary and sufficient for floral organ identity.

\section{Proposal of a revised $A B C$ model: the floral quartet model}

The SEPALLATA (SEP) floral organ identity genes are necessary for the normal development of petals, stamens and carpels and these SEP genes together with the $\mathrm{A}, \mathrm{B}$ and $\mathrm{C}$ functions are sufficient to generate floral organs from leaves (Honma and Goto, 2001, Pelaz et al., 2001b). It has been suggested that the A, B, C and SEP proteins probably act as a multimeric complex in order to activate the downstream genes (Pelaz et al., 2000, Honma and Goto, 2001, Pelaz et al., 2001b, Ferrario et al., 2003). According to this and other data a modification of the $A B C$ model has been proposed (Egea-Cortines and Davies, 2000, Goto et al., 2001, Jack, 2001, Theißen and Saedler, 2001). The revised model includes the SEP function in the three inner whorls represented redundantly by SEP1/2/3. The floral quartet model implies that the MADS-box proteins act as tetrameric complexes in order to specifically bind and, at the same time, to transcriptionally activate the target genes (Egea-Cortines et al., 1999). The transcriptional activation ability is acquire thanks to the recruitment of SEP and/ or AP1 to the quartet, since these are the only proteins among the group with such activity (Honma and Goto, 2001). Supported by the results described above, we conclude that the AP1/AP3/PI/SEP 
protein complex would be needed to modify the "leaf-like ground state" into petals in whorl 2. Thus the AP3/PI/SEP/AG complex would be required for stamen formation in whorl 3 and a smaller complex formed by SEP and AG would be needed for carpel development in whorl 4 . These results do not solve the identity of the quartet formed in whorl 1 for sepal development (Figure 4A).

\section{Revisiting the floral quartet model. SEPALLATA4 un- covers the role of SEP genes in sepal development}

According to the floral quartet model, there is a missing factor in the tetrameric complex of sepal development in whorl 1 (Figure 4A). In spite of the fact that the SEP genes are expressed early in sepal primordia (Ma et al., 1991, Rounsley et al., 1995) and that SEP3 interacts with the AP1 protein (Honma and Goto, 2001, Pelaz et al., 2001a) no alterations were observed in the sepals of sep1 sep2 sep3 triple mutants. This raised the possibility that a redundant gene might mask the role of $S E P 1 / 2 / 3$ in sepal development. Very recently a new SEP gene, SEP4, has been identified. Although the sep4 single mutant did not reveal any phenotype, the quadruple sep 1/2/3/4 mutant displayed indeterminate flowers composed only of leaf-like organs demonstrating that sepal development is dependent on SEP function (Ditta et al., 2004). SEP4 is involved redundantly with the other SEP genes in the development of all floral organ types; sepals, petals, stamens and carpels. Accordingly, although the single sep mutants showed either a subtle or no phenotype (Pelaz et al., 2000, Ditta et al., 2004), the diminishing amounts of SEP function, by increasing the amount of sep mutant alleles, leads to an increasingly stronger phenotype (Favaro et al., 2003, S. Pelaz, unpublished). The leaflike phenotype of the sep1/2/3/4 quadruple mutant flowers resembled that seen in ABC mutants (Bowman etal., 1991), the floral organ identity is lost in the absence of the SEP proteins. This new finding points to the SEP proteins as the missing factor of the tetrameric complex in whorl 1, this complex would be then AP1/ SEP and might specify the sepals in the first whorl (Figure 4B). Therefore, SEP proteins are required in all four whorls and they would be part of all four different protein complexes that would give rise to the development of all four kinds of floral organs: sepals, petals, stamens and carpels (Figure 4B).

\section{Future prospects in flower development}

Although the floral quartet model is broadly accepted still lacks many experimental data for its confirmation. For instance, some of the quartet complexes have been observed in yeasts, but their formation has not been demonstrated in plants. It should be noted that the floral organ identity quartets of proteins are different in each of the different whorls. This seems to indicate that the distinct quartets bind to different specific target genes and, therefore, these genes are activated in only one whorl. The few target genes identified so far do not follow that rule and only the SHP2 MADS box gene, which is a downstream gene of the fourth whorl quartet SEP/AG, is activated in one whorl, the carpels. On the contrary, the $N A P$ gene, which has been identified as a direct target gene of $A P 3$ (Sablowski and Meyerowitz, 1998) is activated in petals and stamens and $S P L / N Z Z$ (downstream of $A G$ ) is activated in stamens and carpels (Ito et al., 2004). What, then, is the functional significance of the different quartets in the different whorls? In order to answer this question the protein complexes need to be isolated from plants to confirm their formation and, on the other hand, more floral organ identity genes should be identified. Both kinds of data will solve this apparent contradiction and will shed new light on our understanding of how a flower is made.

\section{An introduction to fruit development}

Evolution has created a wide variety of different fruits in the angiosperms to ensure survival of these plants through seed dispersal. The fruit is perhaps the most complex organ of the plant, since it is made up of many different cell types and tissues. The dry dehiscent fruit of Arabidopsis thaliana, also called the pod or silique, is representative of the fruit from more than three thousands species of the Brassicaceae family. Its structure reflects its double function. On the one hand, the fruit provides a protective chamber for the seeds during maturation. On the other, the fruit disperses the seeds through the differentiation of several specialized cell types, which form a spring-like mechanism causing the silique to shatter at maturity, thus releasing the seeds into the environment.

The simple Arabidopsis fruit is derived directly from the gynoecium, which consists of two fused carpels (Smyth et al., 1990). At anthesis, when the flower bud opens and anthers dehisce, two major regions can be externally distinguished in the gynoecium: the apical part constituted by the style and stigma and the basal part or ovary containing the ovules (Fig. 5A). Since the Arabidopsis pod develops from the ovary, any mutation that affects ovary development has an effect on fruit development. Much is known about the genetic and hormonal control of the patterning of the gynoecium (Dinneny and Yanofsky, 2005). It has been proposed that the apical-basal axis of the gynoecium is patterned through an auxin gradient, with a concentration of auxin at the apex, which is likely to be its source (Nemhauser et al., 2000). In support of this model, the gynoecia of flowers treated with polar-auxin-transport inhibitors show defects in proximodistal patterning (Okada et al., 1991; Nemhauser et al., 2000), as do mutants affected in genes involved in auxin signalling such as ETTIN (ETT; Sessions and Zambryski, 1995; Nemhauser et al., 2000). As regards the devel-
Fig. 4. New floral quartet model. (A) The floral quartet model includes the SEP function active in the three inner whorls. The quartets of proteins are represented by colored balls. The quartet in the first whorl is missing a factor. (B) Tentative modification of the floral quartet model in which the SEP function is now shown to be active in the four whorls of the flower. The four distinct complexes of proteins are shown, the quartet of the first whorl is probably formed by SEP and AP1 proteins.
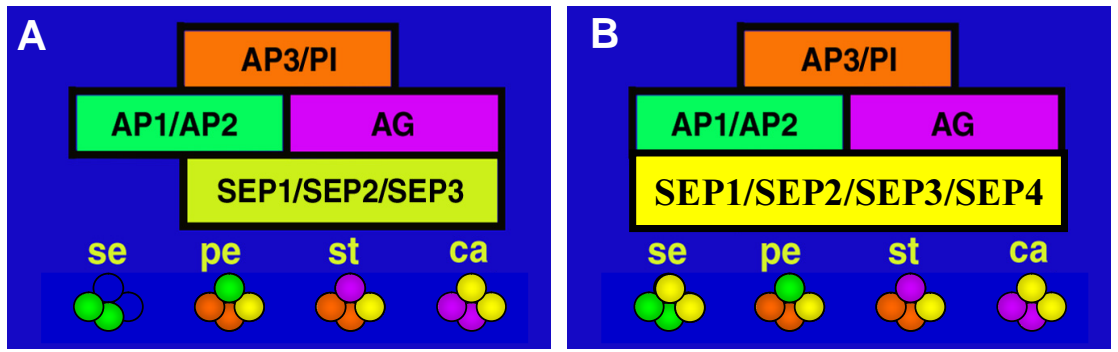

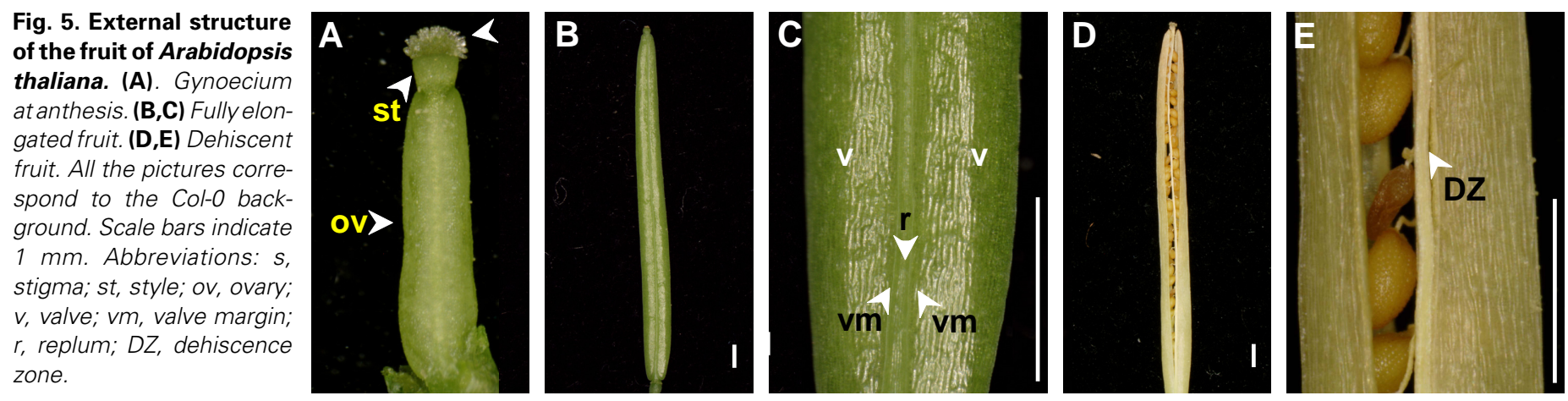

opment of the abaxial adaxial axis of the gynoecium, mutations in genes coding for transcription factors that control the development of lateral organs, such as KANADI1 and KANADI2 (KAN1, KAN2: Eshed et al., 2001; Kerstetter et al., 2001) and CRABS CLAW (CRC; Alvarez and Smyth, 1999, Bowman and Smyth, 1999) also have roles in the gynoecium. Several other genes including SPATULA (SPT; Alvarez and Smith, 1999; Heisler et al., 2001), AINTEGUMENTA (ANT; Elliot et al., 1996; Klucher et al., 1996; Krizek, 1999; Mizukami and Fischer, 2000) redundantly with LEUNIG (LUG; Liu and Meyerowitz, 1995; Conner and Liu, 2000; Liu et al., 2000), affect the development of medial tissues including the stigma, style and transmitting tract. This list includes many genes that are generally involved in patterning lateral organs, which also have effects in the carpels since floral organs are essentially modified leaves (Bowman et al., 1991; Honma and Goto, 2001; Pelaz et al., 2001; Ditta et al., 2004).

All the tissue layers of a mature fruit are already present in the ovary, so once the gynoecium has been fertilized by the pollen, the cells of the ovary keep dividing and growing until the fruit reaches its final length and thickness at maturity, at around 10 days after fertilization. In this way, the mature fruit is mostly constituted by an elongated ovary (Vivian-Smith and Koltunow, 1999) (Fig. 5B). Internally, the pod is made up of two cavities or locules, separated by a septum (Fig. 6A). Externally, three major pattern elements can be distinguished in a silique: the valves, the replum and the valve margins (Fig. 5C and 6A). The valves, the walls of the pod, are made up of 6 cell layers: the external epidermis or exocarp, with long cells and stomata, three layers of photosynthetic tissue or mesocarp and the endocarp, made up of two layers, the Ena, or inner epidermis and the Enb (Fig. 6A). The replum is the middle ridge between the valves that constitutes the framework to which the developing seeds attach to the plant. The third structural components of the fruit are the valve margins that join the valves to the replum (Fig. 5C and 6B). The valve margins are visibly noticeable as a constriction in the boundaries between the valves and the replum as a result of its slower expansion during fruit maturation and they are made up of a few rows of narrow cells. The differentiation of tissues required for fruit opening or dehiscence is, with the exception of the development of the seeds inside the silique, the main developmental process that occurs during Arabidopsis fruit development (Ferrándiz, 2002). At fruit maturity the valve margins become the dehiscence zone (DZ) (Figs. $5 \mathrm{D}-\mathrm{E}$ and $6 \mathrm{~B})$. Before dehiscence, the cells of $\mathrm{DZ}$ next to the valves undergo lignification to form the lignified margin layer and a row of small and isodiametric cells next to the replum become the sepa-

ration layer. The middle lamella between the cells of the separation layer suffer break-down, resulting in loss of cellular cohesion, which, together with subsequent cell death, creates a detachment line between valves and replum (Spence et al., 1995) (Fig. 6C). At the same time, similar processes of hydrolysis and lignification take place in the En $a$ and En $b$, respectively, contributing also to the mechanical opening of the fruit (Fig. 6C). Once the fruit is opened, the simple mechanical force of wind, rain or physical contact will release the seeds from the plant.

This part of the review will focus on the differentiation processes in the ovary after fertilization, that is, in the patterning of the mature fruit. Much of our knowledge about how the fruit is patterned come from the laboratory of Marty Yanofsky, at the University of California, San Diego (UCSD), where classical genetics and molecular biology are being used to identify the genes that are needed to correctly pattern the silique. Because the dehiscence zone is of such importance for seed dispersal and the survival of the species, great progress has been made in identifying the genes involved in specifying the valve margin identity and those involved in positioning the valve margin within the fruit.

\section{FUL and SHP, MADS-box genes pushing the limits}

One of the first described mutants specifically affected in carpel development after fertilization was fruitfull (ful; Gu et al., 1998). Although ful mutations also affect cauline leaf development and meristem identity (Ferrándiz et al., 2000a), their most studied phenotypic effects appear in the fruits. The ful mutant siliques are very small due to a defect in the differentiation of the valve cells. The exocarp cells of ful valves stop growing earlier than the wildtype ones and stomata fail to differentiate. The epidermal replum cells seem to reach a correct size, but acquire a zigzag growing pattern in order to accommodate the replum full length between the small valves. This pattern makes the replum easily visible in the ful background. Cell division control fails in the Ena, since this layer has a larger number of cells that are smaller than the wild-type Ena cells. The process of dehiscence is abnormal in ful mutants. Although the size and the number of seeds per silique is slightly reduced, the poorly elongated ful fruit cannot contain the set of seeds, so the valves often tear open revealing the developing seeds. In addition to the En $b$, which is lignified at dehiscence in wild-type fruits, all the mesocarp layers are lignified in ful fruits (Ferrándiz etal., 2000b). The FUL gene is a member of the MADSbox transcription factors ( $A G L 8$, Mandel and Yanofsky, 1995). FUL expression in the gynoecium starts quite early during flower 
development, is confined to the valves in developing ovaries and is maintained until late fruit development. The first proposed function for FUL, based on the mutant phenotype, was the promotion of cell valve expansion. However, the discovery of two mutants affected in the development of the valve margin caused to reinterpret the FUL function.

The two MADS box genes SHATTERPROOF1 (SHP1, formerly AGL 1) and SHATTERPROOF2 (SHP2, formerly AGL5) are highly redundant at the structural and expression pattern levels (Ma et al., 1991; Savidge et al., 1995; Flanagan et al., 1996) and both are expressed, among other tissues, in the valve margins of fruits. Mutations in only one of these genes do not produce any mutant phenotype. However, the fruits of the double mutant are indehiscent, which shows these genes are also functionally redundant (Liljegren et al., 2000). The shp1shp2 fruits are indehiscent because the separation and lignified margin layers fail to differentiate in the valve margin, resulting in the absence of the DZ. Gainof-function studies revealed that some of the traits of the 35S::SHP1 35S.:SHP2 lines are reminiscent of the ful phenotype. The valves of the fruits overexpressing SHP show defects in both the outer and inner epidermis, they tear open before the seeds reach maturity and are ectopically lignified. The similarity in the phenotypes of 35S::SHP135S::SHP2 fruits and the fulone, hints that the ful phenotype might be reinterpreted as the acquisition of valve margin identity by the valves.

New insights into the function of FUL came from the study of the 35S::FUL gain-of-function lines (Ferrándiz et al., 2000b). The phenotype of these plants resembled that of the shp1shp2 double mutant. In fact, the entire outer surface of 35S::FUL fruit looks like the valve surface, suggesting that both the valve margins and replum have been converted to a valve identity. Moreover, valve margin lignification is missing. Both defects give rise to indehiscent fruits. A well designed suite of molecular and genetic studies shed light on the relationship between $F U L$ and SHPgenes (Ferrándiz etal., 2000b). FUL was found to be the negative spatial regulator of the SHP genes in the valves, since the fu/mutant ectopically expresses $S H P$ genes in the valves, while the SHP expression is abolished in the 35S::FUL fruits. The complementary expression patterns of FUL and SHP and the loss and gain of function phenotypes, suggest that both genes act antagonistically to correctly place the formation of valve margins in the fruit. The question that remained was to what extent was the failure of valve differentiation in ful mutants due to the ectopic expression of the SHP genes. In other words, is the main role of $F U L$ to repress the expression of the SHP genes in the valves, instead of inducing valve development? If this were the case, removal of the SHP activity from the $f u /$ valves would restore the wild-type phenotype. However, Ferrándiz et al. found that although valve development in the ful shp1 shp2 triple mutant fruits is slightly rescued, the valves are far from wild type. These fruits are still quite small and show valve ectopic lignification, which means that the missexpresion of SHP genes in the valves of $f u l$ fruit is not the main factor responsible for its phenotype. This fact left opened the possibility that FUL, besides repressing SHP genes in the valves, has a direct role in promoting valve development and fruit elongation. However, this hypothesis was weakened by the discovery of two new genes, INDEHISCENT and $A L C A T R A Z$, which are involved in the formation of the DZ that were shown to be repressed by FUL in the valves.

\section{IND and $A L C$, two bHLH genes for making the DZ}

The ALCATRAZ (ALC, Rajani and Sundaresan, 2001) gene was identified and characterized in the Venkatesan Sudaresan laboratory. $A L C$ was named after the famous San Francisco Bay's prison, because its mutations give rise to indehiscent fruits, which keep the seeds imprisoned inside. In contrast to shp1shp2 mutants, which affect the whole differentiation of DZ, neither the outer cell morphology nor the lignification pattern of the DZ is affected in alc fruits. Mutations in alc specifically disrupt the formation of the separation layer. In the wild-type siliques, this cell layer, placed between the replum and the lignified cells of the valve margin, is made up of small non-lignified cells whose separation produces the opening of the fruit at maturity. In the alc mutants these cells are bigger and they seem to rupture instead of disassociating. The process of rupture is not complete, since the big cells occupying the inner valve margin become ectopically lignified and hold together the valves and the replum. These unopened siliques can be shattered simply by applying manual pressure to break the ectopic lignified bridge. $A L C$ codes for a protein with a basic helix-loophelix domain (bHLH), which is expressed in the valve margin and dehiscence zone during silique dehiscence. This protein belongs to a family of transcription factors with DNA binding (the basic) and

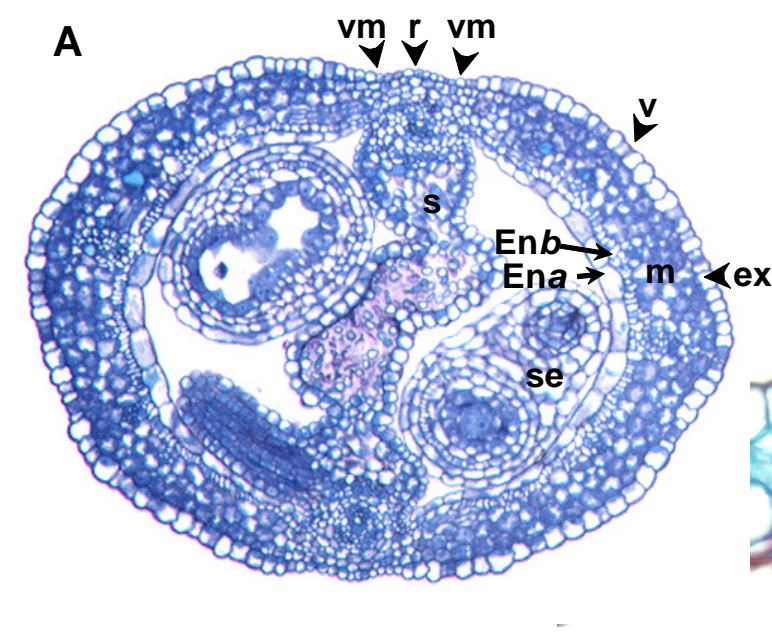

Fig. 6. Internal structure of the fruit of Arabidopsis thaliana. Transverse sections of Landsberg erecta, stages 16 (A) and $17(\mathbf{B})$ and Wassileskija, late stage $17(\mathbf{C})$, fruits. Sections $(\mathbf{B}, \mathbf{C})$ are close ups of the zone including valve margins and replum. Sections $(\mathbf{A}, \mathbf{B})$ have been stained with toluidine blue. while section (C) has been stained with safranin $O$ and alcian blue. In this section lignified tissues appear purple color. Abbreviations: DZ, dehiscence zone; Ena, endocarp layer a; Enb, endocarp layer $b ; \mathrm{Im}$; lignified margin layer; m, mesocarp; r, replum; s, septum; se, seed; sl, separation layer; v, valve; vm, valve margin. Pictures courtesy of Adrienne Roeder 
dimerization (the helix-loop-helix) domains. As with SHP1 and $S H P 2, F U L$ is required to repress $A L C$ expression in the valves. To test whether the ectopic expression of $A L C$ in the ful mutant valves was the primary cause of their failure to differentiate correctly, $A L C$ activity was removed in the alc ful double mutant. The fruits of the double mutant $a / c$ ful, although not wild type, were longer than the ful ones, so the normal pattern of growing and differentiation is restored to some degree by eliminating the ectopic activity of $A L C$ in the valves of ful (Liljegren et al., 2004).

The siliques of the indehiscent (ind) mutants, such as shp1shp2 and alc, also fail to open at maturity (Liljegren et al., 2004). Externally, the valve margins of ind fruits are not so constricted as the wild-type ones. Inside, the cells of the separation zone and lignified cell layers are not visible. So IND seems to be involved in

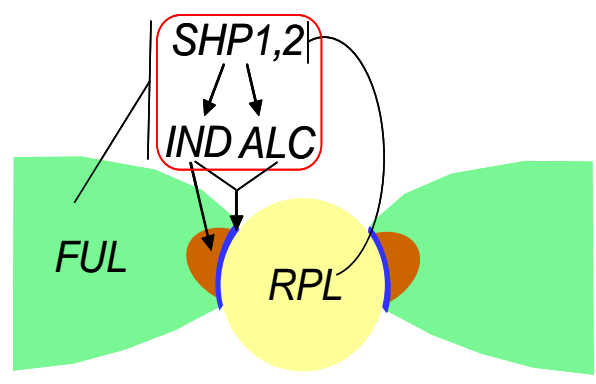

Fig. 7. Network of gene regulation in fruit patterning. Valves are colored in green. The dehiscence zone, DZ, is divided into lignified margin layer, brown, and separation layer, blue. Replum is represented in yellow. SHP1,2 and IND are required for the complete differentiation of DZ, while ALC seems to play a more specific role in separation layer development. Adapted from Dinneny and Yanofsky, 2005.

both processes responsible of fruit opening, cell differentiation of valve margins and lignification. IND, like $A L C$, codes for a bHLH transcription factor and is expressed in the valve margins and the En $b$ layer that will lignify in later stages of fruit development. As with the SHP genes, IND is also ectopically expressed in the valves of the ful mutants. Valve development and fruit elongation are dramatically restored in ind ful double mutants, however restoration of valve development is still not complete.

\section{Unravelling the cascade of gene regulation}

The removal of the different functions ectopically expressed in the ful valves, SHP1 and SHP2, IND and $A L C$, revealed the contribution of these genes to the ful phenotype. Of the different double mutants, the fruits of ind ful are the ones phenotypically closest to the wild-type, whereas the fulshp1 shp2 valves are the least restored. Therefore, the greatest contribution to the ful phenotype is made by IND, ALC and SHP1 SHP2 in that order. Removing all of these activities in the ind alc shp1 shp2 ful quintuple mutant causes a spectacular restoration in valve development almost to normal. However, some defects are still present in the quintuple mutant valves suggesting that either additional factors are still being ectopically expressed or that FUL does in fact have some small direct role in valve development (Liljegren et al., 2004).

The study of expression patterns and genetic interactions between the different mutants affected in the development of valve margins was used to define epistatic relationships and to draw the hierarchical map of the gene functions defining valve margin. The study of expression patterns indicates that SHP1 SHP2 is on top of the network since IND and $A L C$ expression is not detected in the margins of shp1shp2 mutant fruits (Liljegren etal., 2000, 2004). However, there are likely some additional activators of IND which are still unidentified, since there is some residual expression of IND in the valves of the ful shp1 shp2 triple mutant (Ferrándiz et al., 2000b). Genetic studies reveal that the function of SHP1 SHP2 in valve margin development it is not only the activation of IND and $A L C$, since the valve margin of the ind alc shp1 shp2 quadruple mutant is much less defined than in the ind alc double mutant. While SHP1 SHP2 and IND play some role in the differentiation of the lignified and separation valve layer, $A L C$ seems to act more specifically in the development of just the separation layer (Rajani and Sundaresan, 2001).

\section{Making the replum or repressing valve margins again?}

Recently a mutation was identified that affects the third external component of the fruit, the replum. RPL (REPLUMLESS), which codes for a homeodomain protein, seems to play a similar role in the replum as FUL in the valves (Roeder et al., 2003). The RPL gene was identified by screening for mutations affecting replum development using the ful mutant as the genetic background for the mutagenesis, since the replum of ful fruits is visible by eye. In contrast to ful, shp1 shp2 or ind mutants, in which the plant architecture is normal, $r p /$ is affected in the overall plant morphology. In fact, $r p /$ alleles have been characterized by three other groups, each focusing on a different developmental role of this gene (PENNYWISE (PNY), Smith and Hake, 2003; BELLRINGER $(B L R)$, Byrne et al., 2003; Bao, et al., 2004). Instead of a normal replum, the rp/ single mutant develops rows of narrow cells morphologically and molecularly resembling valve margin cells. The rp/ fu/ double mutant fruit is externally encircled by small valve margin-like cells. The study of triple and quadruple mutants reveals that $R P L$ function is not directly required for replum formation. Replum development is restored in rp/ shp1 shp2 and rp/ fulshp1 shp2 mutant, which demonstrates that the ectopic expression of $S H P$ genes is responsible for the conversion of replum cells into valve margin cells and that $R P L$ function is to negatively regulate $S H P$ genes in the replum, avoiding the differentiation toward valve margin of replum cells. In this way, $R P L$ plays the same role in the replum as FUL in the valves. FUL and $R P L$ restrict $S H P$ expression to a narrow strip of cells that will develop into valve margin, thus ensuring fruit dehiscence.

\section{Future prospects in fruit development}

Since the opening of the fruit is essential for the dispersal of seeds, the formation of the valve margins and dehiscence zone is one of the most important developmental processes in fruit development. Genetic and molecular studies have contributed to our knowledge about which genes are needed to create the detachment line responsible for fruit opening, SHP1, SHP2, IND and $A \angle C$ and how these genes have to be actively repressed in the valves by $F U L$ and in the replum by $R P L$, to avoid the spread of valve margin identity (Fig. 7). But little is known about the genes responsible for the identity of valves and replum. Such genes 
would act during gynoecium formation and their functions would be related to the acquisition of a new identity from the basal leaf identity of a primordium initiated from a meristem. One of the goals in forthcoming years will be to investigate the regulatory network between the genes broadly involved in lateral organ development and the fruit specific factors.

Another important goal will be to identify new or additional downstream targets, direct or indirect, of SHP1, SHP2, IND and $A L C$, including other transcription factors and enzymes responsible for the processes that lead to fruit opening such as pectinases, polygalacturonases, cellulases and enzymes for lignin metabolism. Polygalacturonases, for example, have been shown to be related to the process of dehiscence in Arabidopsis and Brassica napus (Petersen et al., 1996; Sander et al., 2001).

As in gynoecium development, auxin also seems to be important for the differentiation of the DZ. A possible role for auxin in repressing dehiscence has been reported in Brassica (Chauvaux et al., 1997). It would be interesting to determine the full extent of the role of auxin in Arabidopsis fruit dehiscence.

Pod shatter at the wrong time due to adverse weather conditions is responsible for considerable losses in several species of agricultural interest such as canola (Brassica napus), from whose seeds oil is obtained. The fruit of canola is quite similar to Arabidopsis, as well as other crops whose fruits are pods. It is likely that the genetic regulatory network uncovered in Arabidopsis will be applicable to these species, so the manipulation of gene expression of the orthologs of FUL, SHP1, SHP2, ALC or IND in crops, may lead to the control of pod shatter. Some promising results in this sense have been obtained in Arabidopsis. The transgenic lines overexpressing FUL (Ferrándiz et al., 2000b), or with a reduced $A \angle C$ function through antisense RNA or dominant negative constructs (Rajani and Sundaresan, 2001) produce pods with defective dehiscence. A similar kind of approach applied to species in which transformation is possible would produce transgenic plants in which dehiscence can be controlled.

Although these crop plants have siliques with a similar morphology to Arabidopsis, other members of the Brassicaceae show fruits with a wide variety of morphologies. It is possible that the level and spatial domains of expression of the orthologs of the FUL, SHP1, SHP2, IND, ALC and RPL genes required to specify and place the DZ may generate morphology diversity in the species of the Brassicaceae family. Loss and gain of function of FUL cause a regular overall change of fruit shape and size in Arabidopsis. The fruits of the ful mutant are small, while overexpression of $F U L$ gives rise to siliques with overgrown valves that reach the same level as the stigma (Ferrándiz et al., 2000b). Perhaps some heart-shaped fruits such as those of the Capsella generum, or rounded fruits such as those of Teesdaliopsis, Hymenolobus or Hornungia can be obtained through the modulation of FUL expression. In a similar way, the phenotype of the Arabidopsis fruits caused by some rp/ mutant alleles are reminiscent of the fruits of some Brassicaceae species, such as Brassica napus, which is characterized by the absence of a replum (Roeder et al., 2003).

\section{Acknowledgements}

We thank Adrienne Roeder for providing the pictures in Figure 6 and John Bowman for pictures in Figure 1 (with permission of Development). We also thank Adrienne Roeder for her helpful critical reading of this review. We are especially grateful to Marty Yanofsky for giving us the opportunity to develop our postdoctoral research in his laboratory. The flower development work is supported by a grant from the Spanish MCYT (BIO2002-01261).

\section{References}

ALVAREZ, J. and SMYTH, D.R. (1999). CRABS CLAW and SPATULA, two Arabidopsis genes that control carpel development in parallel with AGAMOUS. Development 126:2377-2386.

ALVAREZ, J. and SMYTH, D.R. (2002). CRABS CLAW and SPATULA genes regulate growth and pattern formation during gynoecium development in Arabidopsis thaliana. Int. J. Plant Sci. 163:17-41.

AMBROSE, B.A., LERNER, D.R., CICERI, P., PADILLA, C.M., YANOFSKY, M.F. and SCHMIDT, R.J. (2000). Molecular and genetic analyses of the silky1 gene reveals conservation in floral organ specification between eudicots and monocots. Mol. Cel/ 5: 560-579.

AMMERERER, G. (1990). Identification, purification and cloning of a polypeptide (prtf/ grm) that binds to mating-specific promoter elements in yeast. Genes and Development 4: 299-312.

ANGENENT, G.C., FRANKEN, J., BUSSCHER, M., WEISS, D. and VAN TUNEN, A.J. (1994). Co-suppression of the petunia homeotic gene fbp2 affects the identity of the generative meristem. Plant J. 5: 33-44.

BAO, X., FRANKS, R.G., LEVIN, J.Z. and LIU, Z. (2004). Repression of AGAMOUS by BELLRINGER in floral and inflorescence meristems. Plant Cel/ 16:1478-1489.

BOWMAN, J.L. and SMYTH, D.R. (1999). CRABS CLAW, a gene that regulates carpel and nectary development in Arabidopsis, encodes a novel protein with zinc finger and helix-loop-helix domains. Development 126:2387-2396.

BOWMAN, J.L., SMYTH, D.R. and MEYEROWITZ, E.M. (1991). Genetic interactions among floral homeotic genes of Arabidopsis. Development 112: 1-20.

BYRNE, M.E., GROOVER, A.T., FONTANA, J.R. and MARTIENSSEN, R.A. (2003). Phyllotactic pattern and stem cell fate are determined by the Arabidopsis homeobox gene BELLRINGER. Development 130:3941-3950.

CASTILLEJO, C., ROMERA-BRANCHAT, M. and PELAZ, S. (in press). A new role of the Arabidopsis SEPALLATA3 gene revealed by its constitutive expression. Plant J.

CHAUVAUX, N., CHILD, R., JOHN, K., ULVSKOV, P., BORKHARDT, B., PRINSEN, E. and VAN ONCKELEN H. (1997). The role of auxin in cell separation in the dehiscence zone of oilseed rape pods. J. Exp. Bot. 48:1423-1429.

CHEN, X. (2004). A microRNA as a translational repressor of APETALA2 in Arabidopsis flower development. Science 303: 2022-2025.

COEN, E.S. and MEYEROWITZ, E.M. (1991). The war of the whorls: Genetic interactions controlling flower development. Nature 353: 31-37.

CONNER, J. and LIU, Z. (2000). LEUNIG, a putative transcriptional corepressor that regulates AGAMOUS expression during flower development. Proc. Natl. Acad. Sci. USA 97:12902-12907.

DAVIES, B., EGEA-CORTINES, M., DE ANDRADE SILVA, E., SAEDLER, H. and SOMMER, H. (1996). Multiple interactions amongst floral homeotic MADS box proteins. EMBO J. 15: 4330-4343.

DAVIES, B., MOTTE, P., KECK, E., SAEDLER, H., SOMMER, H. and SCHWARZSOMMER, Z. (1999). Plena and farinelli: Redundancy and regulatory interactions between two Antirrhinum MADS-box factors controlling flower development. EMBO J. 18: 4023-34.

DINNENY, J.R. and YANOFSKY, M.F. (2005). Drawing lines and borders: how the dehiscent fruit of Arabidopsis is patterned. Bioessays 27:42-49.

DITTA, G., PINYOPICH, A., ROBLES, P., PELAZ, S. and YANOFSKY, M.F. (2004). The sep4 gene of Arabidopsis thaliana functions in floral organ and meristem identity. Curr. Biol. 14: 1935-1940.

EGEA-CORTINES, M. and DAVIES, B. (2000). Beyond the ABCs: Ternary complex formation in the control of floral organ identity. Trends Plant Sci. 5: 471-476.

EGEA-CORTINES, M., SAEDLER, H. and SOMMER, H. (1999). Ternary complex formation between the MADS-box proteins squamosa, deficiens and globosa is involved in the control of floral architecture in Antirrhinum majus. EMBO J. 18: 5370-5379.

ELLIOTT, R.C., BETZNER, A.S., HUTTNER, E., OAKES, M.P., TUCKER, W.Q., GERENTES, D., PEREZ, P. and SMYTH, D.R. (1996). AINTEGUMENTA, an 
APETALA2-like gene of Arabidopsis with pleiotropic roles in ovule development and floral organ growth. Plant Cell 8: 155-168.

ESHED, Y., BAUM, S.F., PEREA, J.V. and BOWMAN, J.L. (2001). Establishment of polarity in lateral organs of plants. Curr. Biol. 11:1251-1260.

FAN, H.-Y., HU, Y., TUDOR, M. and MA, H. (1997). Specific interactions between the $k$ domains of $A G$ and $A G L s$, members of the MADS domain family of DNA binding proteins. Plant J. 11: 999-1010.

FAVARO, R., PINYOPICH, A., BATTAGLIA, R., KOOIKER, M., BORGHI, L., DITTA, G., YANOFSKY, M.F., KATER, M.M. and COLOMBO, L. (2003). MADS-box protein complexes control carpel and ovule development in Arabidopsis. Plant Cell 15: 2603-2611

FERRANDIZ, C. (2002). Regulation of fruit dehiscence in Arabidopsis. J. Exp. Bot. 53:2031-2038.

FERRANDIZ, C., GU, Q., MARTIENSSEN, R. and YANOFSKY, M.F. (2000a) Redundant regulation of meristem identity and plant architecture by FRUITFULL, APETALA1 and CAULIFLOWER. Development 127:725-34.

FERRANDIZ, C., LILJEGREN, S.J. and YANOFSKY, M.F. (2000b). Negative regulation of the SHATTERPROOF genes by FRUITFULL during Arabidopsis fruit development. Science 289:436-8.

FERRARIO, S., IMMINK, R.G., SHCHENNIKOVA, A., BUSSCHER-LANGE, J. and ANGENENT, G.C. (2003). The MADS box gene fbp2 is required for sepallata function in petunia. Plant Cell 15: 914-25.

FLANAGAN, C.A., HU, Y. and MA, H. (1996). Specific expression of the AGL 1 MADSbox gene suggests regulatory functions in Arabidopsis gynoecium and ovule development. Plant J. 10:343-353.

FORNARA, F., MARZIANI, G., MIZZI, L., KATER, M. and COLOMBO, L. (2003) MADS box genes controlling flower development in rice. Plant Biol. 5: 16-22.

GOETHE, J.W.V. (1790). Versuch die metamorphose der pflanzen zu erklären. C. W. Ettinger, Gotha

GOTO, K., KYOZUKA, J. and BOWMAN, J.L. (2001). Turning floral organs into leaves, leaves into floral organs. Curr. Opin. Genet. Dev. 11: 449-456.

GU, Q., FERRANDIZ, C., YANOFSKY, M.F. and MARTIENSSEN, R. (1998). The FRUITFULL MADS-box gene mediates cell differentiation during Arabidopsis fruit development. Development 125:1509-17

HEISLER, M.G., ATKINSON, A., BYLSTRA, Y.H., WALSH, R. and SMYTH, D.R. (2001). SPATULA, a gene that controls development of carpel margin tissues in Arabidopsis, encodes a bHLH protein. Development 128:1089-1098.

HONMA, T. and GOTO, K. (2001). Complexes of MADS-box proteins are sufficient to convert leaves into floral organs. Nature 409: 525-529.

HUANG, H., TUDOR, M., WEISS, C.A., HU, Y. and MA, H. (1995). The Arabidopsis MADS-box gene $a g / 3$ is widely expressed and encodes a sequence-specific DNA-binding protein. Plant Mol. Biol. 28: 549-567.

HUIJSER, P., KLEIN, J., LÖNNIG, W.-E., MEIJER, H., SAEDLER, H. and SOMMER $H$. (1992). Bracteomania, an inflorescence anomaly, is caused by the loss of function of the MADS-box gene SQUAMOSA in Antirrhinum. EMBO J.11: 12391249

IMMINK, R.G., FERRARIO, S., BUSSCHER-LANGE, J., KOOIKER, M., BUSSCHER, M. and ANGENENT, G.C. (2003). Analysis of the petunia MADS-box transcription factor family. Mol. Genet. Genomics 268: 598-606.

ITO, T., WELLMER, F., YU, H., DAS, P., ITO, N., ALVES-FERREIRA, M., RIECHMANN, J.L. and MEYEROWITZ, E.M. (2004). The homeotic protein AGAMOUS controls microsporogenesis by regulation of sporocyteless. Nature 430: 356-360.

JACK, T. (2001). Relearning our ABCs: New twists on an old model. TRENDS Plant Sci. $6: 310-316$

KANG, H.G., JEON, J.S., LEE, S. and AN, G. (1998). Identification of class B and class $\mathrm{C}$ floral organ identity genes from rice plants. Plant Mol. Biol. 38: 1021-1029.

KERSTETTER, R.A., BOLLMAN, K., TAYLOR, R.A., BOMBLIES, K. and POETHIG, R.S. (2001). KANAD/ regulates organ polarity in Arabidopsis. Nature 411:706709.

KLUCHER, K.M., CHOW, H., REISER, L. and FISCHER, R.L. (1996). The AINTEGUMENTA gene of Arabidopsis required for ovule and female gametophyte development is related to the floral homeotic gene APETALA2. Plant Cell 8:137-153

KOTILAINEN, M., ELOMAA, P., UIMARI, A., ALBERT, V.A., YU, D. and T.H., T. (2000). Grcd1, an AGL2-like mads box gene, participates in the C function during stamen development in Gerbera hybrida. Plant Cell 12: 1893-1902.

KRAMER, E.M., DORIT, R.L. and IRISH, V.F. (1998). Molecular evolution of genes controlling petal and stamen development: Duplication and divergence within the APETALA3 and PISTILLATA MADS-box gene lineages. Genetics 149: 765-783.

KRIZEK, B.A. (1999). Ectopic expression of AINTEGUMENTA in Arabidopsis plants results in increased growth of floral organs. Dev. Genet 25:224-236.

KRIZEK, B.A. and MEYEROWITZ, E.M. (1996a). The Arabidopsis homeotic genes APETALA3 and PISTILLATA are sufficient to provide the $\mathrm{B}$ class organ identity function. Development 122: 11-22.

KRIZEK, B.A. and MEYEROWITZ, E.M. (1996b). Mapping the protein regions responsible for the functional specificities of the Arabidopsis MADS domain organ-identity proteins. P. Natl. Acad. Sci. USA 93: 4063-4070.

LAMB, P. and MCKNIGHT, S.L. (1991). Diversity and specificity in transcriptional regulation: The benefits of heterotypic dimerization. Trends Biochem. Sci. 16:417422.

LILJEGREN, S.J., DITTA, G.S., ESHED, Y., SAVIDGE, B., BOWMAN, J.L. and YANOFSKY, M.F. (2000). SHATTERPROOF MADS-box genes control seed dispersal in Arabidopsis. Nature 404: 766-770.

LILJEGREN, S.J., ROEDER, A.H., KEMPIN, S.A., GREMSKI, K., OSTERGAARD, L. GUIMIL, S., REYES, D.K. and YANOFSKY, M.F. (2004). Control of fruit patterning in Arabidopsis by INDEHISCENT. Cell 116:843-53.

LIU, Z. and MEYEROWITZ, E.M. (1995). LEUNIG regulates AGAMOUS expression in Arabidopsis flowers. Development 121:975-991.

LIU, Z., FRANKS, R.G. and KLINK, V.P. (2000). Regulation of gynoecium marginal tissue formation by LEUNIG and AINTEGUMENTA. Plant Cel/ 12:1879-1892.

MA, H., YANOFSKY, M.F. and MEYEROWITZ, E.M. (1991). AGL1-AGL6, an Arabidopsis gene family with similarity to floral homeotic and transcription factor genes. Gene. Dev. 5: 484-495

MANDEL, A.M. and YANOFSKY, M. F. (1995) The Arabidopsis AGL8 MADS-box gene is expressed in inflorescence meristems and is negatively regulated by APETALA1. Plant Cell 7:1763-1771.

MANDEL, M.A. and YANOFSKY, M.F. (1998). The Arabidopsis AGL9 MADS-box gene is expressed in young flower primordia. Sex. Plant Reprod. 11: 22-28.

MENA, M., AMBROSE, B.A., MEELEY, R.B., BRIGGS, S.P., YANOFSKY, M.F. and SCHMIDT, R.J. (1996). Diversification of C-function activity in maize flower development. Science 274: 1537-1540.

MEYEROWITZ, E.M., SMYTH, D.R. and BOWMAN, J.L. (1989). Abnormal flowers and pattern formation in floral development. Development 106: 209-217.

MIZUKAMI, Y. and MA, H. (1992). Ectopic expression of the floral homeotic gene AGAMOUS in transgenic Arabidopsis plants alters floral organ identity. Cel/ 71 : 119-131.

MIZUKAMI, Y. and FISCHER, R.L. (2000). Plant organ size control: AINTEGUMENTA regulates growth and cell numbers during organogenesis. Proc. Natl. Acad. Sci. USA 97:942-947.

MIZUKAMI, Y., HUANG, H., TUDOR, M., HU, Y. and MA, H. (1996). Functional domains of the floral regulator AGAMOUS: Characterization of the DNA binding domain and analysis of dominant negative mutations. Plant Cel/ 8: 831-845.

MOON, Y.-H., KANG, H.-G., JUNG, J.-Y., JEON, J.-S., SUNG, S.-K. and AN, G. (1999). Determination of the motif responsible for interaction between the rice APETALA1/AGAMOUS-like9 family proteins using a yeast two-hybrid system. Plant Physiol. 120: 1193-1203.

MOURADOV, A., GLASSICK, T.V., HAMDORF, B.A., MURPHY, L.C., MARLA, S.S., YANG, Y. and TEASDALE, R.D. (1998). Family of MADS-box genes expressed early in male and female reproductive structures of Monterey pine. Plant Physiol. 117: 55-62.

MOURADOV, A., HAMDORF, B., TEASDALE, R.D., KIM, J.T., WINTER, K.U. and THEISSEN, G. (1999). A DEF/GLO-like MADS-box gene from a gymnosperm: Pinus radiata contains an ortholog of angiosperm b class floral homeotic genes. Dev. Genet. 25: 245-252.

NEMHAUSER, J.L., FELDMAN, L.J. and ZAMBRYSKI, P.C. (2000). Auxin and ETTIN in Arabidopsis gynoecium morphogenesis. Development 127:3877-3888.

NORMAN, C., RUNSWICK, M., POLLOCK, R. and TREISMAN, R. (1988). Isolation and properties of CDNA clones encoding srf, a transcription factor that binds to the c-fos serum response element. Cell 55: 989-1003.

OKADA, K., UEDA, J., KOMAKI, M.K., BELL, C.J. and SHIMURA, Y. (1991) 
Requirement of the auxin polar transport system in early stages of Arabidopsis floral bud formation. Plant Cell 3:677-684.

PELAZ, S., DITTA, G.S., BAUMANN, E., WISMAN, E. and YANOFSKY, M.F. (2000). $\mathrm{B}$ and $\mathrm{C}$ floral organ identity functions require sepallata MADS-box genes. Nature 405: 200-203.

PELAZ, S., GUSTAFSON-BROWN, C., KOHALMI, S.E., CROSBY, W.L. and YANOFSKY, M.F. (2001a). APETALA1 and SEPALLATA3 interact to promote flower development. Plant J. 26: 385-94.

PELAZ, S., TAPIA-LOPEZ, R., ALVAREZ-BUYLLA, E.R. and YANOFSKY, M.F. (2001b). Conversion of leaves into petals in Arabidopsis. Curr. Biol. 11: 182-4.

PETERSEN, M., SANDER, L., CHILD, R., VAN ONCKELEN, H., ULVSKOV, P. and BORKHARDT, B. (1996). Isolation and characterisation of a pod dehiscence zone-specific polygalacturonase from Brassica napus. Plant Mol. Biol. 31:517527.

PNUELI, L., HAREVEN, D., BRODAY, L., HURWITZ, C. and LIFSCHITZ, E. (1994). The TM5 MADS box gene mediates organ differentiation in the three inner whorls of tomato flowers. Plant Cel/ 6: 175-186.

RAJANI, S. and SUNDARESAN, V. (2001). The Arabidopsis myc/bHLH gene ALCATRAZ enables cell separation in fruit dehiscence. Curr. Biol. 11:1914-22.

RIECHMANN, J.L. and MEYEROWITZ, E.M. (1997a). Determination of floral organ identity by Arabidopsis MADS domain homeotic proteins AP1, AP3, PI and AG is independent of their DNA- binding specificity. Mol. Biol. Cell 8: 1243-59.

RIECHMANN, J.L. and MEYEROWITZ, E.M. (1997b). MADS domain proteins in plant development. Biol. Chem. 378: 1079-1101.

RIECHMANN, J.L., KRIZEK, B.A. and MEYEROWITZ, E.M. (1996). Dimerization specificity of Arabidopsis MADS domain homeotic proteins APETALA1, APETALA3, PISTILLATA and AGAMOUS. Proc. Natl. Acad. Sci. USA 93: 47934798

ROEDER, A.H., FERRANDIZ, C. and YANOFSKY, M.F. (2003). The role of the REPLUMLESS homeodomain protein in patterning the Arabidopsis fruit. Curr. Biol. 13:1630-5.

ROUNSLEY, S.D., DITTA, G.S. and YANOFSKY, M.F. (1995). Diverse roles for MADS box genes in Arabidopsis development. Plant Cell 7: 1259-1269.

RUTLEDGE, R., REGAN, S., NICOLAS, O., FOBERT, P., COTE, C., BOSNICH, W., KAUFFELDT, C., SUNOHARA, G., SEGUIN, A. and STEWART, D. (1998). Characterization of an AGAMOUS homologue from the conifer black spruce (Picea mariana) that produces floral homeotic conversions when expressed in Arabidopsis. Plant J. 15: 625-634.

SABLOWSKI, R.W. and MEYEROWITZ, E.M. (1998). A homolog of NO APICAL MERISTEM is an immediate target of the floral homeotic genes APETALA3/ PISTILLATA. Cel/ 92: 93-103.

SANDER, L., CHILD, R., ULVSKOV, P., ALBRECHTSEN, M. and BORKHARDT, B. (2001). Analysis of a dehiscence zone endo-polygalacturonase in oilseed rape (Brassica napus) and Arabidopsis thaliana: evidence for roles in cell separation in dehiscence and abscission zones and in stylar tissues during pollen tube growth. Plant Mol. Biol. 46:469-479.

SAVIDGE, B., ROUNSLEY, S.D. and YANOFSKY, M.F. (1995). Temporal relationship between the transcription of two Arabidopsis MADS box genes and the floral organ identity genes. Plant Cel/ 7: 721-733.

SESSIONS, R.A. and ZAMBRYSKI, PC. (1995). Arabidopsis gynoecium structure in the wild type and in ettin mutants. Development 121:1519-1532.

SHORE, P. and SHARROCKS, A.D. (1995). The MADS box family of transcription factors. Eur. J. Chem. 229: 1-13.

SMITH, H.M. and HAKE, S. (2003). The interaction of two homeobox genes, BREVIPEDICELLUS and PENNYWISE, regulates internode patterning in the Arabidopsis inflorescence. Plant Cell. 15:1717-27.

SMYTH, D.R., BOWMAN, J.L. and MEYEROWITZ, E.M. (1990). Early flower development in Arabidopsis. Plant Cell 2:755-767.

SOMMER, H., BELTRÁN, J.P., HUIJSER, P., PAPE, H., LÖNNIG, W.-E., SAEDLER, H. and SCHWARZ-SOMMER, Z. (1990). DEFICIENS, a homeotic gene involved in the control of flower morphogenesis in Antirrhinum majus: The protein shows homology to transcription factors. EMBO J. 9: 605-613.

SPENCE, J., VERCHER. Y., GATES, P. and HARRIS, N. (1996). 'Pod shatter' in Arabidopsis thaliana, Brassica napus and B. juncea. J. Microsc. 181:195-203.

TANDRE, K., ALBERT, V.A., SUNDÅS, A. and ENGSTRÖM, P. (1995). Conifer homologues to genes that control floral development in angiosperms. Plant Mol. Biol. 27: 69-78.

TANDRE, K., SVENSON, M., SVENSSON, M.E. and ENGSTROM, P. (1998). Conservation of gene structure and activity in the regulation of reproductive organ development of conifers and angiosperms. Plant J.15: 615-623.

THEIBEN, G. and SAEDLER, H. (2001). Floral quartets. Nature 409: 469-471.

TRÖBNER, W., RAMIREZ, L., MOTTE, P., HUE, I., HUIJSER, P., LÖNNIG, W.-E., SAEDLER, H., SOMMER, H. and SCHWARZ-SOMMER, Z. (1992). GLOBOSA A homeotic gene which interacts with DEFICIENS in the control of Antirrhinum floral organogenesis. EMBO J. 11: 4693-4704.

VANDENBUSSCHE, M., ZETHOF, J., SOUER, E., KOES, R., TORNIELLI, G.B., PEZZOTTI, M., FERRARIO, S., ANGENENT, G.C. and GERATS, T. (2003). Toward the analysis of the petunia MADS box gene family by reverse and forward transposon insertion mutagenesis approaches: B, C and D floral organ identity functions require SEPALLATA-like MADS box genes in petunia. Plant Cell 15: 2680-93.

VIVIAN-SMITH, A. and KOLTUNOW, A.M. (1999). Genetic analysis of growthregulator-induced parthenocarpy in Arabidopsis. Plant Physiol. 121:437-51.

YANOFSKY, M.F., MA, H., BOWMAN, J.L., DREWS, G.N., FELDMANN, K.A. and MEYEROWITZ, E.M. (1990). The protein encoded by the Arabidopsis homeotic gene AGAMOUS resembles transcription factors. Nature 346: 35-39.

ZHANG, P., TAN, H.T., PWEE, K.H. and KUMAR, P.P. (2004). Conservation of class $C$ function of floral organ development during 300 million years of evolution from gymnosperms to angiosperms. Plant J. 37: 566-77. 